\title{
A Case of Acinic Cell Carcinoma Associated with Ranula in Sublingual Gland
}

\author{
Yoon Seok Choi ${ }^{1}$, Chang Hoon Bae ${ }^{1}$, Yong-Dae Kim ${ }^{1,2}$, and Si-Youn Song ${ }^{1}$ \\ ${ }^{I}$ Department of Otorhinolaryngology-Head and Neck Surgery, College of Medicine, Yeungnam University, Daegu; and \\ ${ }^{2}$ Regional Center for Respiratory Diseases, Yeungnam University Medical Center, Daegu, Korea
}

\section{하마종을 동반한 설하선 선방세포암 1 예}

최윤석 ${ }^{1} \cdot$ 배창훈 $^{1} \cdot$ 김용대 ${ }^{1,2} \cdot$ 송시연 ${ }^{1}$

영남대학교 의과대학 이비인후-두경부외과학교실, ${ }^{1}$ 영남대학교병원 권역 호흡기 전문질환센터 ${ }^{2}$

\author{
Received December 26, 2014 \\ Revised February 9,2015 \\ Accepted February 11, 2015 \\ Address for correspondence \\ Si-Youn Song, $\mathrm{MD}, \mathrm{PhD}$ \\ Department of Otorhinolaryngology- \\ Head and Neck Surgery, \\ College of Medicine, \\ Yeungnam University, \\ 170 Hyeonchung-ro, Nam-gu, \\ Daegu 42415, Korea \\ Tel $+82-53-620-3782$ \\ Fax $+82-53-628-7884$ \\ E-mailssykhs@med.yu.ac.kr
}

Acinic cell carcinoma (ACC) is a low-grade malignancy of salivary gland that constitutes approximately $17 \%$ of primary salivary gland malignancies. ACC predominantly occurs in the parotid gland. The higher incidence in the parotid gland seems to be related with the serous acinar cells of the glands, while the sublingual gland is a mixed gland, predominantly mucinous. Therefore, ACCs which originated in the sublingual gland are very rare and till now only 8 cases have been reported in the literature. Recently, we experienced a case of ACC which was found incidentally in the surgical specimen of a ranula arising in the sublingual gland. The finding of this case suggests that the early pathological diagnosis is needed to clarify the reasons for the recurrence of a ranula. Korean J Otorhinolaryngol-Head Neck Surg 2015;58(9):637-40

\section{서 론}

정상 선방세포와 조직학적으로 유사한 선방세포암(acinic cell carcinoma)은 1953년까지 병리학적으로 양성종양의 경과 를 보이는 선종(adenoma)으로 여겨졌다. 그러나, 그 이후 여러 보고에서 이 종양이 악성종양에서 관찰되는 잦은 재발과 주위 림프절 전이 및 원격전이를 일으키는 것으로 밝혀져 선방세포 암으로 불리게 되었다.'

선방세포암은 췌장, 유방, 폐, 비인강과 타액선 등 다양한 부 위에서 발생하는 것으로 보고되며, 그 중 주타액선에서 주로 발생하고, 주타액선 중에서는 이하선에서 대부분 발생한다. ${ }^{2-6)}$ 선방세포암이 악하선과 설하선에서 발생하는 경우는 드문 것 으로 알려져 있고, 그 중 설하선에 선방세포암이 발생한 경우 는 전 세계적으로 8예가 보고될 정도로 극히 드물며, 국내에는 아직 보고된 바가 없다. ${ }^{70}$ 또한, 저자들이 경험한 증례처럼 하 마종과 함께 선방세포암이 발견된 경우는 단 1 예밖에 없다. 하
마종은 타액선관의 절단이나 파열에 의해 유출된 타액과 주변 결체 조직 간의 염증반응이나 타액선관의 부분적 폐쇄 등에 의한 타액선 상피조직의 증식에 의해 발생하는 것으로 알려져 있으며, 타액선 종양, 화농성 육아종, 타액관 결석, 혈관종, 림 프관종 등과 감별이 필요한 질환이다. ${ }^{11)}$

저자들은 최근 재발한 하마종 치료를 위해 우측 설하선 절 제술을 시행한 젊은 여자 환자에서 설하선에서 발생한 선방세 포암 1 예를 경험하였기에 문헌 고찰과 함께 보고하는 바이다.

\section{증 려}

16세 여자 환자가 우측 구강저에 반복하여 발생하는 낭성 종물로 인한 구강 불편감을 주소로 방문하였다. 환자는 4년 전 같은 증상으로 본원 이비인후과 외래를 방문하여 하마종으로 처음 진단받았으며, 한 차례 조대술을 시행받은 과거력이 있 었다. 이후 6 개월 뒤 재발하여 환자에게 낭종 및 우측 설하선 

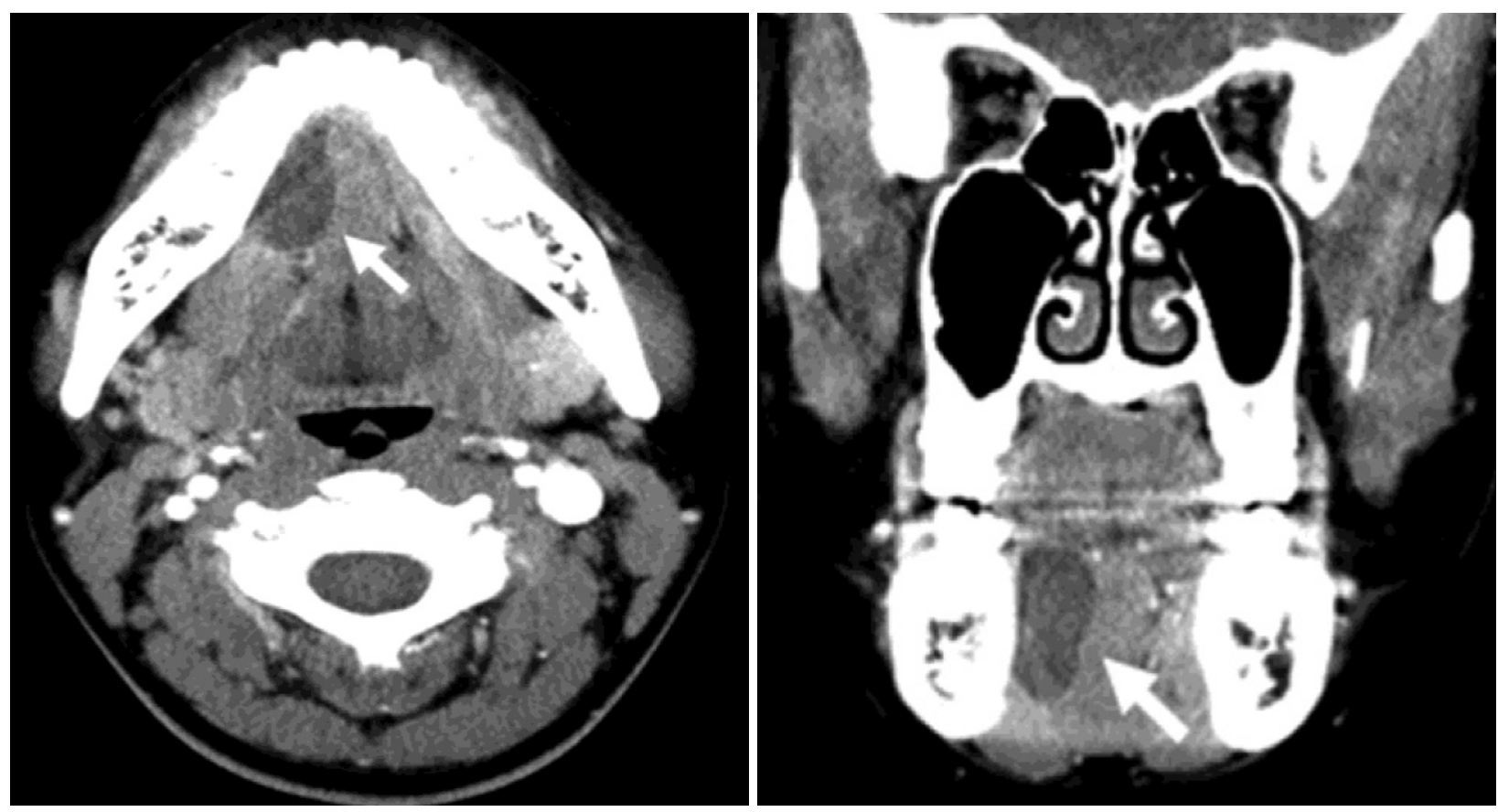

Fig. 1. Preoperative axial and coronal contrast enhanced CT images show about $2.8 \times 1.5 \mathrm{~cm}$ sized well margined homogenous low density mass without enhancement on the left side of the floor of mouth (arrow).
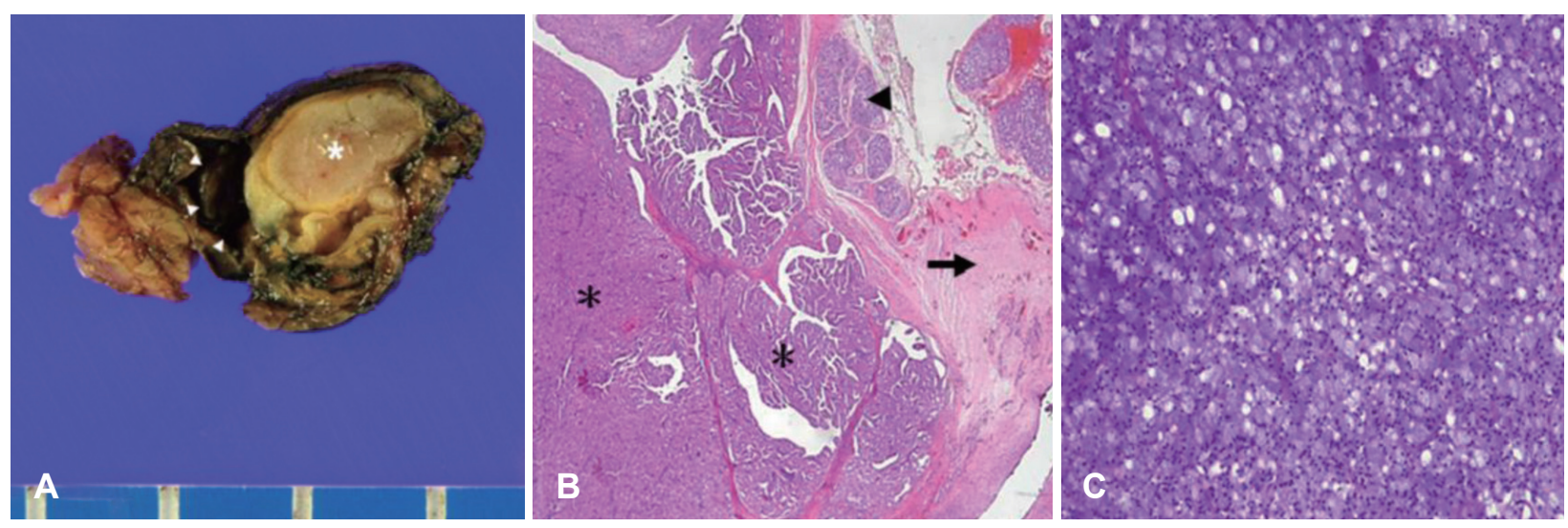

Fig. 2. Gross and histopathologic findings. It measures $2.0 \times 1.7 \times 1.5 \mathrm{~cm}$ sized single mass. The cut surface of the specimen shows a yellowish homogenous solid mass (asterisk) accompanied by cyst (arrowheads) and normal salivary gland structures around the mass (A). The acinic cell carcinoma (asterisk) with adjacent the cyst wall (arrow) and normal glandular tissue (arrowhead) (hematoxylin and eosin stain, $\times 40)(B)$. Tumor cells have chromatin-dense small nuclei proliferate and finely vacuolated cytoplasm with partially periodic-acidSchiff (PAS) reactive (PAS stain, $\times 200)(C)$.

절제술을 권유하였으나, 수술을 거부하고 지내던 중 증상이 지 속되어 4년 뒤 재방문하였다.

외래에서 시행한 이학적 검사상 우측 구강저에 약 $1.5 \times 1.5$ $\mathrm{cm}$ 크기의 통증 없는 낭성 종물이 관찰되었으며, 경부 전산 화단층촬영검사상 우측 구강저에 $2.8 \times 1.5 \mathrm{~cm}$ 크기의 주변과 경계가 비교적 명확하고, 조영증강을 보이지 않으며, 내부가 균일한 저음영의 낭성 종물이 관찰되었다. 종단면(coronal view) 사진에서 낭성 종물은 악설골근(mylohyoid muscle)의 상부에 국한되어 있었고, 낭종 주위에 주변 조직과 음영 차이 를 보이거나 조영이 증강되는 종물 소견은 관찰할 수 없었으
며, 경부의 의미 있는 림프절 비대는 관찰되지 않았다(Fig. 1). 증상 완화 및 진단 목적으로 구강을 통한 세침흡인세포검사 를 시행하였고, 세포조직검사상 조직구와 중성구만 관찰되었 으며, 악성종양을 의심할 만한 소견은 보이지 않았다. 이에 설 하선에 발생한 하마종으로 판단하여 전신마취하에 낭종을 포함한 우측 설하선 절제술을 시행하였다. 우측 구강저 점막 에 악하선관의 주행방향을 따라 악하선관과 하악골 사이에 절개를 가한 후 점막박리를 시작하였다. 낭종과 설하선을 완 전 적출하였으며, 수술 중 설신경과 악하선관은 보존하였다. 수술소견상 낭종을 포함한 설하선과 주위 조직 간의 유착 또 
는 침범 소견이 보이지 않아 동결절편검사는 시행하지 않았으 며, 환자는 수술 후 4일째 특별한 합병증이 보이지 않아 퇴원 하였다.

수술 중 제거한 검체는 $4.0 \times 3.4 \mathrm{~cm}$ 크기로 주변 연부조직과 의 유착은 보이지 않았으며, 피막이 잘 보존되어 있었다. 육안 검사상 종물은 $2.0 \times 1.7 \mathrm{~cm}$ 크기의 황색 고형성 종물과 $2.0 \times$ $1.3 \mathrm{~cm}$ 크기의 낭종이 함께 붙어 있었으며, 고형성 종물의 일 부가 낭종 안으로 침윤된 소견이 관찰되었다(Fig. 2A). 저배 율 현미경검사에서 종양세포와 함께 주위에 낭종의 섬유성 격막과 정상 타액선 조직이 관찰되었으며(Fig. 2B), periodicacid-Schiff(PAS) 염색 후 시행한 고배율 현미경 검사에서는 원형의 핵과 풍부한 세포질을 함유하고, $\mathrm{PAS}$ 에 양성을 보이 는 종양세포들이 관찰되었다(Fig. $2 \mathrm{C}$ ). 추가로 시행한 면역조직 화학 염색에서도 alpha-1-antitrypsin, S100 protein, cytokeratin 7, 8, 9에 양성소견이 보여 최종적으로 선방세포암으로 진단하였다.

수술 직후 원격전이 유무를 확인하기 위해 시행한 양전자 방 출단층촬영술(positron emission tomography-computed tomography, PET-CT)상에서는 전이를 의심할 만한 소견은 보이지 않았고, 최종 병리조직 검사상 종양은 피막에 잘 쌓여 있었으며, 절개면에서 종양세포가 관찰되지 않아 추가적인 경 부청소술과 수술 후 방사선 치료는 시행하지 않았다. 환자는 현재 6개월간 재발이나 합병증 없이 외래 추적관찰 중이다.

\section{고 찰}

선방세포암은 타액선에서 발생하는 원발성 악성종양의 $17 \%$ 를 차지한다. 타액선 중 이하선에서 가장 흔하게 발생하며,' 설 하선과 소타액선에 발생하는 경우는 매우 드물다. ${ }^{7-10)}$ 이는 선 방세포암이 타액선의 분비성 세포 중 장액선 세포에서 기원한 암종이기 때문에 장액선 조직이 대부분인 이하선에서 흔하게 발생하지만 장액선보다는 점액선 조직이 풍부한 혼합성 타액 선인 설하선에서는 드물게 발생한다. ${ }^{7)}$

선방세포암은 임상적으로 서서히 자라는 종괴가 주증상이 며, 통증이나 안면신경마비와 같은 증상이 나타나는 경우가 흔하지 않아 발견이 늦어지는 경우가 많고, 림프절 전이나 원 격전이는 드물지만, 수술 후 재발률은 8 35\% 정도로 비교적 높게 보고되고 있다.,6) 치료는 이환된 타액선을 주변 정상조직 을 포함하여 넓게 제거하는 것이며, 예방적 경부청소술은 고려 되지 않는다. 그러나, 치료 전 림프절 전이가 확인된 경우에는 경부청소술을 함께 시행하고, 수술 후 보조적 치료로 방사선 요법이 사용되기도 한다.)

선방세포암은 임상적 악성도가 저도(low grade)로 분류되는
종양으로 5년 생존율이 88 91\%이며, 타액선암 중 가장 예후 가 좋다. 하지만, 조직학적으로 역분화(dedifferentiated) 또는 미분화(undifferentiated) 형태일 경우에는 생존율이 감소하고, 재발 및 전이가 흔하게 발생한다. ${ }^{12)}$ 예후에 영향을 미치는 요인 으로는 종양의 크기, 위치, 세포의 분열 정도, 림프절 전이 유무, 신경침범 유무 등이 있다. ${ }^{6}$ 본 증례는 선방세포암이 설하선에 발생한 매우 드문 경우로 수술 시 종양의 주위 조직 침범이 관 찰되지 않았고, 악하선관, 설신경 및 설하신경의 침범이 보이지 않았으며, 수술 후 시행한 PET-CT검사상 경부림프절 전이나 원격전이가 관찰되지 않아 예후는 양호할 것으로 생각된다.

설하선에 발생한 종양은 대부분 우연히 발견되는 경우가 많고, 발견 당시 구강 불편감 외에 특이 증상이 없는 경우가 대 부분이며, 종양이 상당히 진행되어야 통증이나 설부 감각이상 을 호소하기 때문에 진단이 늦어지게 된다. ${ }^{13)}$ 본 증례에서도 환 자는 구강 불편감 외에 다른 증상은 없었으며, 우측 구강저 부 위에 재발한 하마종의 근본적 치료를 위해 설하선 절제술을 시행한 후 병리학적 검사에서 우연히 선방세포암으로 진단된 경우이다. 수술 전 시행한 이학적 검사, 영상학적 검사와 조직 검사에서 악성종양을 예측할 만한 소견은 관찰되지 않았고, 수술 소견에서도 악성종양이 의심되는 소견은 보이지 않았다. 또한, 가장 최근에 보고된 Matsuzaka 등ㄲㅇㅢ 보고와 유사하 게 하마종과 선방세포암이 함께 발견된 증례이다. 보고된 증 례가 많지 않고, 하마종과 종양 발생의 선후관계를 알 수 없어 두 질환의 상관관계를 명확히 알 수 없지만, 하마종 발생기전 과 연관지어 생각해볼 때, 종양에 의해 타액선관이 파괴되어 도관 외부로 타액이 유출되고 주변 결체조직으로 흡수되어 염증반응이 일어나 결체조직성 피막을 형성한 것으로 생각해 볼 수 있다. ${ }^{11}$

하마종은 유피낭종, 농양, 설관낭종, 후두낭종 및 갑상선 낭종 등과 유사하고, ${ }^{11)}$ 본 증례와 같이 타액선암, 타액선염, 타 석증 등으로 인해 이차적으로 발생할 수도 있기 때문에 다양 한 질환과의 감별이 필요하다.,11) 하마종의 고식적인 치료법은 낭종 및 관련된 타액선을 모두 제거하는 것이며, $\mathrm{OK}-432$ 를 이용한 경화요법, 미세조대술(micro-marsupialization), $\mathrm{CO}_{2}$ 레이저 치료, 냉동요법 등 다양한 치료법이 있고, 각 치료법마 다 재발률이나 성공률에 차이가 있다.11) 그러나 본 증례와 같 이 매우 드물지만 악성종양이 동반된 하마종의 가능성을 고 려한다면, 이학적 검사에서 낭종 주위에 고형성 종괴가 만져지 거나, 방사선학적 검사에서 낭종 주위에 다른 종물이 동반된 소견을 보일 경우, 그리고 경화치료를 포함한 다양한 치료에 반응하지 않거나 치료 후에도 재발하는 경우 타액선 종양의 가능성을 배제하기 위해 반드시 낭종과 함께 관련 타액선의 외과적인 절제가 필요할 것으로 사료된다. 
본 증례를 통해 치료 반응이 좋지 않거나, 재발 성향을 보이 는 하마종의 경우 하마종 발생의 원인이 될 수 있는 타액선암, 타액선염, 타석증 등의 질환에 대한 감별을 위해 세심한 검사 가 필요하며, 고식적인 수술 치료법을 통한 명확한 병리학적 진 단이 필요할 것으로 생각된다.

\section{REFERENCES}

1) Godwin JT, Foote FW Jr, Frazell EL. Acinic cell adenocarcinoma of the parotid gland; report of twenty-seven cases. Am J Pathol 1954;30 (3):465-77.

2) Hamidian Jahromi A, Shokouh-Amiri H, Wellman G, Hobley J, Veluvolu A, Zibari GB. Acinar cell carcinoma presenting as a duodenal mass: review of the literature and a case report. J La State Med Soc 2013;165:20-3, 25.

3) Limite G, Di Micco R, Esposito E, Sollazzo V, Cervotti M, Pettinato G, et al. Acinic cell carcinoma of the breast: review of the literature. Int $\mathrm{J}$ Surg 2014;12 Suppl 1:S35-9.

4) Yoo JD, Kim HS, Lee SC, Kim YM. A case of acinic cell carcinoma of parotid gland in childhood. Korean J Otolaryngol-Head Neck Surg 1992;35(3):462-5.

5) Jung PG, Lee DY, Hong NP, Ahn HY, Cha CI. A case of nasopharyngeal acinic cell carcinoma. Korean J Otorhinolaryngol-Head Neck Surg 1994; 37(4):817-23.

6) Al-Zaher N, Obeid A, Al-Salam S, Al-Kayyali BS. Acinic cell carcinoma of the salivary glands: a literature review. Hematol Oncol Stem Cell Ther 2009;2(1):259-64.

7) Matsuzaka K, Shibahara T, Murakami S, Lee DH, Shimono M, Inoue T. Acinic cell carcinoma found by recurrence of a mucous cyst in the sublingual gland. Bull Tokyo Dent Coll 2004;45(2):95-8.

8) Ota Y, Arai I, Aoki T, Yamazaki H, Karakida K, Tsukinoki K. Acinic cell carcinoma of the sublingual gland accompanied by bone formation. Tokai J Exp Clin Med 2001;26(4-6):127-30.

9) du Toit DF, Heydenrych JJ. Acinic cell carcinoma of the sublingual gland. S Afr Med J 1992;82(5):373.

10) van den Akker HP, Busemann-Sokole E, Becker AE. Acinic cell carcinoma of the sublingual gland. Scintigraphy in pre-operative evaluation. Int J Oral Surg 1981;10(5):363-6.

11) Park SG, Park NS, Cho CS, Kim AY, Chang DS, Lee HY, et al. Clinical and histological analysis of oral mucocele. Korean J OtorhinolaryngolHead Neck Surg 2013;56(6):359-64.

12) Nagao T. "Dedifferentiation" and high-grade transformation in salivary gland carcinomas. Head Neck Pathol 2013;7 Suppl 1:S37-47.

13) Rinaldo A, Shaha AR, Pellitteri PK, Bradley PJ, Ferlito A. Management of malignant sublingual salivary gland tumors. Oral Oncol 2004;40(1):2-5. 